DOI: $10.21802 /$ artm.2019.2.10.20.

УДК 615.246 .8

\title{
ВИВЧЕННЯ ГОСТРОЇ ТОКСИЧНОСТІ ВПЕРШЕ ОТРИМАНИХ ЕКСТРАКТІВ ШАВЛІЇ ЛІКАРСЬКОї
}

\author{
Ю.В. Верховодова, І.В. Кіреєв, О.М. Кошовий, М.М. Мига, С.Є. Молочна
}

Начіональний фармачевтичний університет, кафедра фармакотерапї̈, м. Харків, Україна, ORCID ID: 0000-0002-5047-375X, ORCID ID: 0000-0002-5413-9273,

ORCID ID: 0000-0001-9545-8548, Scopus ID: 34978866400,

ORCID ID: 0000-0003-0748-9358, ORCID ID: 0000-0003-2871-9597, e-mail: Juliaverh73@gmail.com

Резюме. Актуальним напрямком сучасної фармації $є$ пошук та створення нових лікарських засобів 3 рослинної сировини вітчизняного походження. Фармакологічна оцінка профілю безпеки $є$ важливим етапом.

Шавлія лікарська в народній медицині використовується для лікування запальних хвороб ротової порожнини, кишечника. Ця рослина росте на території України і $є$ перспективним джерелом отримання сировини. Вона містить у собі велику кількість біологічно активних речовин: амінокислоти, фенолкарбонові та гідроксикоричні кислоти, флавоноїди, ефірні олії, терпеноїди та хлорофіли та ін.

Мета роботи. Вивчення гострої токсичності вперше отриманих похідних екстракту шавлії лікарської (екстракт №1-11).

Матеріали і методи. При одноразовому внутрішньошлунковому введенні досліджуваних екстрактів у дозах 500 мг/кг, 4000 мг/кг, 6000 мг/кг було використано 216 мишей (36 груп по 6 тварин). Тварини були попередньо індивідуально помічені та утримані на голодуванні 3 години. Після проходження 14 діб констатували кількість загиблих мишей. Проаналізували летальність.

Результати та обговорення. Надані фітосубстанції були отримані вперше та згідно з літературними даними щодо шавлії лікарської можуть проявляти широку фармакологічну активність, тому першим етапом дослідження стало вивчення їх гострої токсичності. Екстракти № 1-11 відносяться до класу V, вони практично нетоксичні згідно з загальноприйнятою класифікацією за К.К. Сидоровим. Результати представлені у вигляді таблиці.

Висновки. Була вивчена гостра токсичність вперше отриманих екстрактів шавлії лікарської, екстракти № 1-11 відносяться до класу $\mathrm{V}$, вони практично нетоксичні згідно з загальноприйнятою класифікацією за К.К. Сидоровим, що може служити підставою для обгрунтування подальшого вивчення екстрактів шавлії лікарської.

Ключові слова: екстракти, шавлія лікарська, гостра токсичність.

Вступ. Під час лікування антибіотиками і до 12 тижнів після його завершення у до $30 \%$ пацієнтів реєструється антибіотик-асоційована діарея [1]. Вона виникає у зв'язку з лікуванням антибіотиками, без інших видимих причин, в тому числі із-за гострого порушення нормальної кишкової флори. Найпоширенішою причиною антибіотик-асоційованої діареї серед дітей і дорослих є Clostridium difficile. C. difficile інфекція, пов'язана зі значною захворюваністю і смертністю. Препаратами вибору для лікування клостридіальної інфекції $\epsilon$ метронідазол (побічні ефекти: втрата апетиту, кандидоз, діарея, запаморочення, головний біль, нудота, блювота, атаксія, темна сеча, реакція дисульфірамного типу з етанолом, пухнастий язик, гіперчутливість, нейтропенія, металевий смак, невропатія, панкреатит, тромбофлебіт, ксеростомія, енцефалопатія, асептичний менінгіт, оптична нейропатія, синдром Стівенса-Джонсона, токсичний епідермальний некроліз, зниження лібідо); ванкоміцин (побічні ефекти: еритематозний висип на обличчі та верхній частині тіла, синдром червоної шиї, гіпотензія, нудота і блювота, озноб, лікарська лихоманка, еозинофілія, висип, периферичні набряки, інфекція сечовивідних шляхів, біль у спині, головний біль, оборотна нейтропенія, флебіт [2]. Саме тому пошук та створення сучасних лікарських препаратів рослинного походження 3 антимікробними та протизапальними властивостями $€$ актуальним завданням сучасної науки.

Обгрунтування дослідження. Цілеспрямоване вивчення профілю безпечності фітосубстанцій $\epsilon$ важливим етапом та актуальним напрямком у дослідженні фармакологічних властивостей рослин та їх похідних.

Шавлія лікарська (Salvia officinalis) - розповсюджена рослина на території України. Інтерес як вітчизняних, так і зарубіжних вчених до цієї рослини зростає у зв'язку з відкриттям та детальнішим вивченням різних класів біологічно активних речовин та їх фармакологічної дії [3].

Найбільша кількість біологічно активних сполук міститься у листі шавлії. Вони мають бактерицидну, антитоксичну, протизапальну, протигнильну, спазмолітичну, секретолітичну, кровоспинну, болезаспокійливу, в'яжучу дію. 
За літературними даними відомо, що шавлію лікарську використовують у фітотерапії, народній медицині та кулінарії багатьох країн світу.

Мета дослідження. Вивчити гостру токсичність доз 500 мг/кг, 4000 мг/кг, 6000 мг/кг маси тіла нових фітосубстанцій з листя шавлії лікарської.

Матеріали і методи дослідження. Кафедрою фармакогнозії під керівництвом д. фарм. наук, проф. О.М. Кошовим були синтезовані і надані деякі комплекси шавлії лікарської: екстракт №1 - сухий екстракт на основі відвару листя шавлії (відвар шавлії), екстракт №2 - сухий екстракт з листя шавлії, одержаний 50\% етанолом (50\% екстракт шавлії), екстракт №3 - сухий екстракт з листя шавлії, одержаний 96\% етанолом (96\% екстракт шавлії), екстракт №4 - комплекс фенольних сполук з L-лізином (лізиновий комплекс), екстракт №5 - комплекс фенольних сполук 3 аргініном (аргініновий комплекс), екстракт №6 - полісахаридний комплекс, екстракт №7 - очищений комплекс, екстракт №8 - сапоніновий комплекс, екстракт №9 - фенольний комплекс, екстракт №10 - флавоноїдний комплекс, екстракт №11 - комплекс гідрофільних фенольних сполук.

Для вивчення гострої токсичності використовували вперше отримані екстракти 3 листя шавлії лікарської, які були отримані на кафедрі фармакогнозії Національного фармацевтичного університету під керівництвом д. фарм. наук, проф. О.М.Кошового.

Відповідно до методичних рекомендацій із доклінічного вивчення лікарських засобів дослідження середньосмертельної дози токсичності нових лікарських засобів або субстанцій відібрані після карантину і попередньо індивідуально помічені тварини розподілялись на групи за методом випадкового ви- бору. Перед оральним введенням досліджуваної фітосубстанції тварини голодували 3 години. За допомогою спеціального зігнутого металевого зонда екстракти вводили внутрішньошлунково. Після перорального введення екстрактів допуск до їжі надавався через 3 години. За тваринами спостерігали щодня 14 діб, фіксуючи дату загибелі. Оскільки листя шавлії лікарської широко застосовується в медицині та $\epsilon$ нетоксичною сировиною, вивчили гостру токсичність фітосубстанцій з листя шавлії лікарської при внутрішньошлунковому введенні на мишах - у дозах III, IV, $\mathrm{V}$ класів токсичності (за методичними рекомендаціями 3 доклінічного вивчення лікарських засобів). Через низьку токсичність фармакологічної речовини не можна визначити ЛД50, максимальна доза, яка була введена тваринам 6000 мг/кг маси тіла.

Результати дослідження та їх обговорення. Шавлія лікарська містить феноли, флавоноїди, гідроксикоричні кислоти, полісахариди, амінокислоти, макро- та мікроелементи.

Надані фітосубстанції були отримані вперше та згідно $з$ даними літератури щодо шавлії лікарської можуть проявляти широку фармакологічну активність, тому першим етапом дослідження стало вивчення їх гострої токсичності. Гостру токсичність екстрактів шавлії лікарської вивчали з використанням 216 лабораторних мишей (12 груп по 6 тварин, 3 до3и), яких поділили на групи: екстракт №1-12. Після завершення експерименту (через 14 діб) встановили, що екстракти № 1-11, що відносяться до класу V, практично нетоксичні згідно 3 загальноприйнятою класифікацією за К.К. Сидоровим. Результати представлені у таблиці 1.

Результати дослідження гострої токсичності екстрактів шавлії лікарської

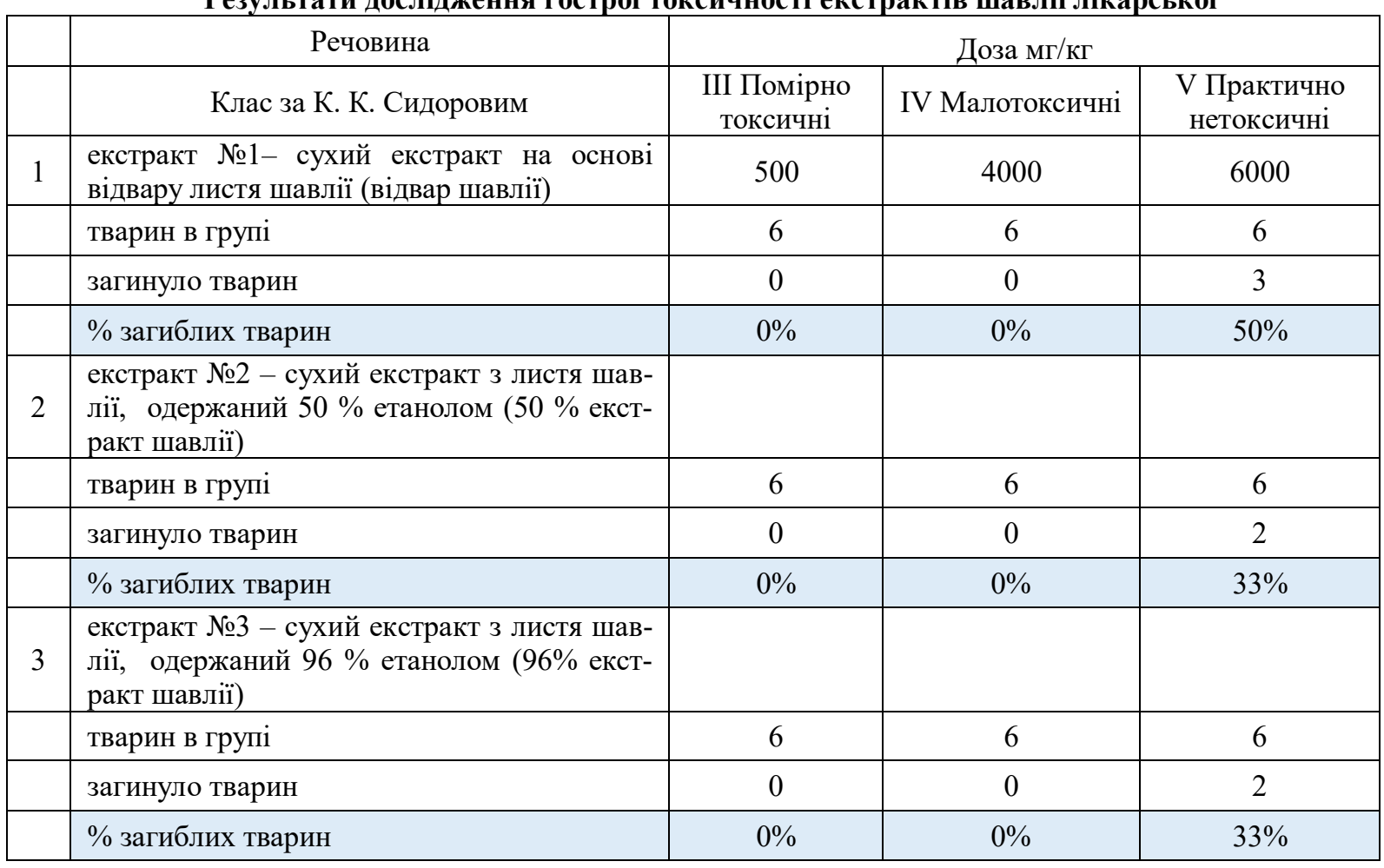




\begin{tabular}{|c|c|c|c|}
\hline $4 \mid$\begin{tabular}{l|l} 
екстракт №4 - комплекс фенольних сполук \\
3 L-лізином (лізиновий комплекс)
\end{tabular} & & & \\
\hline тварин в групі & 6 & 6 & 6 \\
\hline загинуло тварин & 0 & 0 & 3 \\
\hline \% загиблих тварин & $0 \%$ & $0 \%$ & $50 \%$ \\
\hline $\begin{array}{l}\text { екстракт №5 - комплекс фенольних сполук } \\
3 \text { аргініном (аргініновий комплекс) }\end{array}$ & & & \\
\hline тварин в групі & 6 & 6 & 6 \\
\hline загинуло тварин & 0 & 0 & 3 \\
\hline \% загиблих тварин & $0 \%$ & $0 \%$ & $50 \%$ \\
\hline екстракт №6 - полісахаридний комплекс & & & \\
\hline тварин в групі & 6 & 6 & 6 \\
\hline загинуло тварин & 0 & 1 & 3 \\
\hline \% загиблих тварин & $0 \%$ & $17 \%$ & $50 \%$ \\
\hline екстракт №7 - очищений комплекс & & & \\
\hline тварин в групі & 6 & 6 & 6 \\
\hline загинуло тварин & 0 & 1 & 3 \\
\hline \% загиблих тварин & $0 \%$ & $17 \%$ & $50 \%$ \\
\hline екстракт №8 - сапоніновий комплекс & & & \\
\hline тварин в групі & 6 & 6 & 6 \\
\hline загинуло тварин & 0 & 0 & 3 \\
\hline \% загиблих тварин & $0 \%$ & $0 \%$ & $50 \%$ \\
\hline екстракт №9 - фенольний комплекс & & & \\
\hline тварин в групі & 6 & 6 & 6 \\
\hline загинуло тварин & 0 & 0 & 4 \\
\hline \% загиблих тварин & $0 \%$ & $0 \%$ & $67 \%$ \\
\hline екстракт №10 - флавоноїдний комплекс & & & \\
\hline тварин в групі & 6 & 6 & 6 \\
\hline загинуло тварин & 0 & 1 & 3 \\
\hline \% загиблих тварин & $0 \%$ & $17 \%$ & $50 \%$ \\
\hline $\begin{array}{l}\text { екстракт №11 - комплекс гідрофільних } \\
\text { фенольних сполук }\end{array}$ & & & \\
\hline тварин в групі & 6 & 6 & 6 \\
\hline загинуло тварин & 0 & 0 & 4 \\
\hline \% загиблих тварин & $0 \%$ & $0 \%$ & $67 \%$ \\
\hline Контроль & & & \\
\hline тварин в групі & 6 & 6 & 6 \\
\hline загинуло тварин & 0 & 0 & 0 \\
\hline \% загиблих тварин & $0 \%$ & $0 \%$ & $0 \%$ \\
\hline
\end{tabular}

\section{Висновки:}

1. Вивчили гостру токсичність шавлії лікарської, екстракти № 1-11, що відносяться до класу V, практично нетоксичні згідно з загальноприйнятою класифікацією за К.К. Сидоровим.
2. Усе описане вище може служити підставою для обгрунтування подальшого вивчення екстрактів шавлії лікарської. 
References:

1. Elseviers MM, Van Camp Y. Prevalence and management of antibiotic associated diarrhea in general hospitals. BMC infectious diseases. 2015; 15:129.

2. Ana Elena Pérez-Cobas, Andres Moya. Colonization Resistance of the Gut Microbiota against Clostridium difficile. Antibiotics. 2015.

3. Nizhenkovska IV, Tsurkan OO. Shavliia likarska suchasni aspekty zastosuvannia (Ohliad literatury). Fitoterapiia.Chasopys. 2014; 2:58-61.

\section{УДК 615.246 .8 \\ ИЗУЧЕНИЕ ОСТРОЙ ТОКСИЧНОСТИ ВПЕРВЫЕ ПОЛУЧЕННЫХ ЭКСТРАКТОВ ШАЛФЕЯ ЛЕКАРСТВЕННОГО}

Ю.В. Верховодова, И.В. Киреев, О.Н. Кошевой, М.М. Мыга, С.Е. Молочная

Национальный фармацевтический университет, кафедра фармакотерапии,

2. Харьков, Украина,

ORCID ID: 0000-0002-5047-375X,

ORCID ID: 0000-0002-5413-9273,

ORCID ID: 0000-0001-9545-8548,

Scopus ID: 34978866400 ,

ORCID ID: 0000-0003-0748-9358,

ORCID ID: 0000-0003-2871-9597,

e-mail: Juliaverh73@gmail.com

Резюме. Актуальным направлением современной фармации является поиск и создание новых лекарственных средств из растительного сырья отечественного происхождения. Фармакологическая оценка профиля безопасности является важным этапом.

Шалфей лекарственный в народной медицине используется для лечения воспалительных заболеваний ротовой полости, кишечника. Шалфей лекарственный содержит большое количество биологически активных веществ: аминокислоты, фенолкарбоновые и гидроксикоричные кислоты, флавоноиды, эфирные масла, терпеноиды и хлорофиллы и др.

Цель работы. Изучение острой токсичности впервые полученных производных экстракта шалфея (экстракт №1-11).

Материалы и методы. При однократном внутрижелудочном введении исследуемых экстрактов в дозах 500 мг/кг, 4000 мг/кг, 6000 мг/кг было использовано 216 мышей (36 групп по 6 животных). Животные были предварительно индивидуально помечены и удержаны на голодании 3 часа. После прохождения 14 дней констатировали количество погибших мышей. Проанализировали летальность.

Результаты и обсуждение. Предоставленные фитосубстанции были получены впервые и согласно литературным данным по шалфею могут проявлять широкую фармакологическую активность, поэтому первым этапом исследования стало изучение их острой токсичности. Экстракты № 1-11 относятся к классу V, они практически нетоксичны согласно общепринятой классификации по К.К. Сидорову. Результаты представлены в виде таблицы.

Выводы. Была изучена острая токсичность впервые полученных экстрактов шалфея, экстракты № 1-11 относятся к классу $\mathrm{V}$, практически нетоксичны согласно общепринятой классификации по К.К. Сидорову. Все вышеприведенное может быть поводом для обоснования дальнейшего изучения экстрактов шалфея.

Ключевые слова: экстракты, шалфей лекарственный, острая токсичность.

\section{UDC 615.246.8 \\ THE STUDY OF ACUTE TOXICITY OF FIRST OBTAINED SALVIA OFFICINALIS EXTRACTS}

\author{
Y.V. Verkhovodova, I.V. Kireev, O.M. Koshovyi, \\ M.M. Myha, S.E. Molochna
}

National Unversity of Pharmacy, pharmacotherapy department, Kharkiv, Ukraine,

ORCID ID: 0000-0002-5047-375X,

ORCID ID: 0000-0002-5413-9273,

ORCID ID: 0000-0001-9545-8548,

Scopus ID: 34978866400 ,

ORCID ID: 0000-0003-0748-9358,

ORCID ID: 0000-0003-2871-9597,

e-mail: Juliaverh73@gmail.com

Abstract. Antibiotic-associated diarrhea is reported in up to $30 \%$ of patients treated with antibiotics and up to 12 weeks after completion. It arises from the treatment with antibiotics, without other obvious causes, including acute violation of normal intestinal flora. The most common cause of antibiotic-associated diarrhea among children and adults is Clostridium difficile (C. difficile). C. difficile infection is associated with significant morbidity and mortality. Drugs of choice for treatment of clostridia infections are metronidazole (side effects: loss of appetite, candidiasis, diarrhea, dizziness, headache, nausea, vomiting, ataxia, dark urine, fluffy tongue, hypersensitivity, neutropenia, metallic taste, neuropathy, pancreatitis, seizures, thrombophlebitis, xerostomia, encephalopathy, aseptic meningitis, optical neuropathy, Stevens-Johnson syndrome, toxic epidermal necrolysis, decreased libido); vancomycin (side effects: erythematous rash on the face and upper body, red neck syndrome, hypotension, nausea and vomiting, chills, drug fever, eosinophilia, rash, peripheral edema, urinary tract infection, back pain, headache, reversible neutropenia, phlebitis. Therefore, the actual direction of modern pharmacy is the search and the creation of new medicinal products from plant origin of native origin. Pharmacological assessment of the safety profile is an important step.

Salvia officinalis is a widespread plant on the territory of Ukraine and is a promising source of raw materials. The interest of both domestic and foreign scientists to this plant increases in connection with the discovery and more detailed study of various classes of biologically active substances and their pharmacological action. 
The largest number of biologically active compounds is contained in the leaf of Salvia officinalis: monosaccharides, amino acids, phenol carboxylic and hydroxycinnamic acids, flavonoids, terpenoids and chlorophylls a and $b$, essential oil (1,8-cineol, $\alpha$-tuyon, $\beta$-thyon, camphor, borneol), and others . They have bactericidal, antitoxic, anti-inflammatory, anti-rotten, antispasmodic, secreto-lytic, hemostatic, analgesic, astringent action.

According to the literary data, it is known that sage is used in phytotherapy, folk medicine and cooking in many countries of the world.

Aim. Study of acute toxicity of the first obtained derivatives of Salvia officinalis extract (extract №1-11).

Materials and methods. For single intragastric administration of the studied extracts at doses of 500 $\mathrm{mg} / \mathrm{kg}, 4000 \mathrm{mg} / \mathrm{kg}, 6000 \mathrm{mg} / \mathrm{kg} 216$ mice (36 groups of 6 animals) were used. The animals were pre-individually labeled and kept on fasting for 3 hours. After passing 14 days, the number of dead mice was determined. They analyzed mortality.

Results and discussion. The phytosubstances provided were first obtained and, according to the literature data on medicinal sage, may have a broad pharmacological activity, so the first stage of the study was the study of their acute toxicity. Extracts No. 1-11 are practically nontoxic in class $\mathrm{V}$ according to the generally accepted classification by K.K. Sidorov. The results are presented as a table.

Conclusions. The acute toxicity of the first extracts of medicinal sage was studied, extracts No. 1-11 belonging to the class $\mathrm{V}$ are practically non-toxic according to the generally accepted classification for K.K. Sidorov. All the above mentioned can serve as the basis for the further study of Salvia officinalis extracts. toxicity.

Keywords: extracts, Salvia officinalis, acute Стаття надійшла в редакцію 16.05.2019 р. 